\title{
FARM TOURISM IN WALES. PRODUCTS AND MARKETS, RESOURCES AND CAPABILITIES. THE EXPERIENCE OF SIX FARM TOURISM OPERATORS.
}

\author{
Mandy Talbot ${ }^{1}$
}

Received 20 November 2012; Accepted 20 September 2013

\begin{abstract}
Wales' high quality natural environment is a key attraction for tourists from more urban parts of the UK and this has provided opportunities for many farmers to diversify into tourism. This study provides a qualitative examination of the experience of six farm tourism operators, whose businesses are performing well. The study examines the farm tourism operators' resources and capabilities and how these have contributed towards the performance of their businesses in order to provide examples to other farmers. The study identifies the key resources that farmers have drawn on in creating their tourism products and found these to be: a favourable location, the working farm, farm land and buildings, farm produce, the farm family, the farmer's business ethos and the business's reputation. It also highlights the market appeal of these resources to different tourist markets. The research also finds that this group of farmers has demonstrated the necessary capabilities to transform their resources into tourism products that meet evolving market needs. The study highlights that farmers have identified market gaps, niches and trends to cater for in developing their businesses and that they have focused on maintaining the quality and utility of their tourism product. It found that these factors have influenced their business performance. The study also examines the extent to which agriculture (in this case the working farm and farm produce) features as part of the farm tourism product. It concludes that there is scope for a greater focus on agriculture in the farm tourism sector in Wales and that this could create a stronger farm tourism product.
\end{abstract}

Key words: Farm Tourism, Farm Diversification, Tourism Product, Resources, Tourism Markets, Capabilities, Wales

\footnotetext{
1 Mandy Talbot (PhD Candidate), School of Management and Business, Aberystwyth University, Penglais, Aberystwyth, Ceredigion, SY23 3DD, UK; e-mail: amt13@aber.ac.uk
} 


\section{Introduction}

\section{Background}

Making a living from farming alone can be challenging especially in less favourable areas for farming such as Wales and as such farmers in these areas tend to follow multiple income strategies. Wales' high quality natural environment is a key attraction for tourists from more urban parts of the UK and this has provided opportunities for farms to diversify into tourism. Farmers are well placed to cater for tourists as they have a wide range of resources on which to draw in creating their products. However these resources cannot explore themselves and a farmer also needs skills or capabilities to be able to transform them and create new businesses (McNally 2001, Grande 2011). This study therefore identifies both the resources that farm tourism operators have drawn on in creating their tourism products and the capabilities that they possess that have enabled them to do so. Philips et al. (2010) study highlighted that the extent to which agriculture features as part of the farm tourism product can vary from where the farm is just the backdrop to the visit (for example tourist accommodation that just happens to be on a farm) to products where agriculture is a key component. Tourist demand is evolving and visitors are increasingly expecting agriculture as part of the tourism product. This study also considers the extent to which agriculture (in this case the working farm and farm produce) features as part of the tourism product and how it could feature more centrally.

\section{Farm Diversification}

Farm diversification is a common response from farms across the world to changing market conditions and policy and the resulting uncertain financial returns from agriculture. Farm diversification is the diversion of farm based resources: land, labour and other assets on farm to non-traditional agricultural activities (Ilbery 1991). Farm diversification initially started as a grassroots initiative led by farm families (Ploeg 2008, McNally 2001) with the aim of providing additional income streams to build the economic resilience of the farm and farm-household and enable the continuation of farming. Farm diversification was adopted as policy by the UK government in the late 1980s when the Farm Diversification Grant Scheme was first introduced by the then Ministry for Agriculture, Fisheries and Food (MAFF). Since then a number of schemes offering both advice and financial incentives, have facilitated farm diversification with the aim of addressing rural decline (Walford 2001).

Making an income from farming alone has always proved to be a challenge for farmers in Wales. Here most farms are small, family owned businesses that lie within Less Favourable Areas (LFAs) for farming on uplands, slopes and in areas of high rainfall (Welsh Government, Farm Business Survey 2007). Production is mostly suited to sheep and beef with some dairy farming in lowland areas. Being located in an LFA means that farming is highly challenging with smaller yields and as a result the sector is highly dependent on subsidies with the single farm payment (SFP) making up on average $88 \%$ of all farm business incomes (Welsh Rural Observatory (WRO) 2010). Over the years studies have shown that many small farms in LFAs around Europe have followed multiple income strategies in order to support and enable the survival of the farm and farm household (Bateman and Ray, 1994; Meert et al, 2005, Lopezi-Gelats et al 2011). Recent research on farm income strategies in Wales conducted by the WRO 2010 showed that this is still very much the case today. The study showed that:

- $50 \%$ of farmers had at least one non-agricultural diversified enterprise

- $60 \%$ had taken part in agri-environmental schemes at some stage

- $10 \%$ produced organic goods

- $41 \%$ generated off-farm incomes (for example employment off the farm)

The WRO's (2010) research highlighted that these income sources are important contributors to farm household incomes. The research also highlighted that a further $30 \%$ of farmers intend to further diversify their activities due to the future challenges and uncertainties including the potential reductions in farming subsidies, changes to the Welsh agri-environmental scheme and the continued cost-price squeeze in agriculture. 


\section{Farm Tourism in Wales}

Woods (2011) noted that as long as produce has rolled into cities from the countryside, there have been pleasure-seekers that have headed in the other direction to pursue leisure. As the population is becoming increasingly urbanised the numbers heading to the countryside for leisure is growing. Today, the countryside is very much a place for leisure consumption due to the rise of a lifestyle led and leisure orientated society (Walmsey 2003 and Jenkins). This and declining incomes from agriculture is very much reflected in rural incomes. In England and Wales, total spending from visitors to the countryside is more than twice that of the income from agriculture. Figures from The Department for the Environment, Farming and Rural Affairs (DEFRA) 2007, show that tourism generated $£ 12$ billion a year in rural England while agricultural production generated just $£ 5.6$ billion. In Wales outputs from agriculture were just $£ 1.2$ billion GBP while tourism in rural areas was worth $£ 2.5$ billion (Welsh Economic Research Unit 2010). This highlights the importance of tourism to rural economies, particularly in LFAs which are characterised by low incomes from farming and where there are few other economic opportunities.

The majority of tourists to Wales originate from within the UK (mostly England) and come on daytrips, short beaks and longer holidays mainly for leisure purpose (Welsh Government, Wales Visitor Survey 2011). Visitors' main reason for coming to Wales is to experience its high quality natural environment which provides many attractive upland and coastal areas for leisure (Welsh Government, Wales Visitor Survey 2011). Wales has three national parks and several other specially designated areas along with vast expanses of undesignated countryside which all provide opportunities for sightseeing and experiencing rural life. This is appealing to the UK's large urban population which reached about $80 \%$ of the population in England in 2010 (Office for National Statistics 2012). The UK has long had a large urban population due to its early industrialisation and as such many people in the UK have lost their connection with the countryside.

Over the last few decades, tourism and leisure has provided many opportunities for farmers to diversify their businesses into farm tourism operations. The Dartington Trust (1974) described farm tourism as 'any tourism or recreation venture based on a working farm' and many subsequent definitions have also followed this premise. However later definitions have highlighted that farm tourism could be an alternative activity to farming (Ilbery et al 1998) or that it should actually feature the working farm environment as part of the product (Clarke 1999). Hence definitions vary. Clark (1996) highlights that farm tourism can include: farm accommodation (serviced, self-catering and camping), amenities (restaurants, cafes, farmshops, etc.), leisure activities (horse-riding, fishing etc.), attractions (museums and education centres), access (footpaths and bridleways) and events (farm open days, guided tours and farming demonstrations). Research by the WRO (2010) found that farmers in Wales were engaged in the following farm tourism activities:

$10 \%$ tourist accommodation

7\% equestrian activities (including liveries)

$4 \%$ other leisure activities (including attractions)

$4 \%$ retail

Welsh Government figures show that overnight tourist volume and spend decreased by $2.3 \%$ and 10\% respectively between 2011 and 2012 (Great Britain Tourism Survey Volume and Value, 2011, 2012). This indicates that while a few less tourists are coming to Wales they are spending a lot less money. While tourist numbers and spend in the early years of the economic downturn remained steady, recent figures may indicate that tourism in Wales is now being impacted. This may affect the farm tourism sector and prove to be either a challenge or an opportunity depending on the product offered. 


\section{Farm Tourism Products and Markets}

\section{The Farm Tourism Product}

The Tourism product can be defined as any offer facilitating the travel and activity of individuals away from their home environment (Smith 1994). Smith identifies the tourism product as a holistic offering consisting of: the core attraction, which attracts people to the area and the augmentation. In the case of Wales, the natural and cultural heritage is the core attraction. The augmentation is the service and hospitality provided by the operator or in the case of farm tourism, the farmer. The augmentation can also be described as the commercial good. Added to this is the tourist's experience of their visit, their motivation for travel and their engagement with the tourism product.

The core attraction of tourism in rural areas of Wales is the natural and cultural heritage that the country has to offer. In a drive to promote the distinctiveness of Wales as a holiday destination, The Wales Tourist Board (now known as Visit Wales) developed a 'Sense of Place' initiative to encourage tourism businesses to capture the core qualities of Wales in their tourism products (or commercial offerings). Businesses were encouraged to promote and incorporate local features including: prominent people, the Welsh language, local produce, buildings, the arts and the outdoors into their tourism product with the aim of adding value to and increasing the competitiveness of their tourism product (Wales Tourist Board 2005). Farm tourism operators have the potential to go a step further and promote a sense of place through their farms. Farmers already play an important role in the creation and management of the landscape that visitors enjoy. They can also promote a sense of place by providing visitors with the opportunity to experience and learn about agriculture and rural life in the area that they are visiting as well as by providing them with the opportunity to buy or consume local or farm produced goods. Basing the farm tourism product on local agriculture could create a stronger farm tourism product, promote local produce and create a stronger identity for Wales.

The Welsh Government's Farming Food and the Countryside Strategy (2009) highlighted that while many farmers were engaged in tourism, there were opportunities for more synergy between agriculture, local food products, the landscape and wildlife management and leisure pursuits. The strategy added that brought together these rural elements could covey a powerful message about a location as an attractive place to visit. Farm tourism and tourism in rural areas generally in Wales is a highly fragmented sector with no single uniting strategy. Strategic planning for tourism in rural areas is currently covered thematically for example by food, activity and cultural tourism action plans. The development of a farm tourism strategy document could effectively bring all the elements of the sector together, guide its development and promote its identity.

The Welsh Governments over-arching tourism strategy 'Achieving Our Potential' (2006) focuses on strengthening and expanding tourism by offering high quality, innovative tourism products that respond to evolving market needs. By drawing on the sense of place and agriculture in their tourism products farm tourism operators can contribute towards this goal.

\section{Evolving market demands}

Tourist demands of rural areas are evolving. These days, tourists are seeking a multi-sensory experience of the countryside (Woods 2011). Originally tourism focused mainly on the visual consumption of an unspoilt countryside, taking in views and sightseeing. Although tourists may take part in a wider range of activities today, research by the Welsh Government (2009) highlights that a high quality environment is still the key element that visitors seek from their visit to the Welsh countryside.

However, Cloke and Perkins (2002) highlighted that many tourists do not just want to be onlookers in the rural environment; they want a fully embodied rural experience. They emphasize that tourists want to be placed in the rural environment and to move through, touch and feel the rural landscape and have a more intense experience. There are increasing opportunities for this in Wales. There is a growing number of national walking, cycling, and 
riding trails; an increasing number of purpose built mountain biking centres and a growing number of opportunities to take part in mountain and water based adventure activities.

Another trend is that visitors are increasingly recognising and expecting the working farm environment as part of the overall tourism product (Busby and Rendle 2000, Garrod 2010). Such experiences could range from an opportunity to see real-life commercial farming in action to a staged performance of farming especially put on for the tourists (Busby and Rendle 2000). Woods (2011) also noted the existence of commodified farm experiences where petting enclosures and working farm holidays provide the opportunity for participants to have contact with farm animals.

Another development is food tourism where tourists can experience the countryside through taste (Woods 2011). The Food Tourism Action Plan for Wales (2009) highlights that visitors want locally sourced, organic food and that the drive for this is: taste, freshness, food-miles and support for local producers. Food and drink is a major tourism product component and expression of local culture that can add to the identity of the region. As well as good food, the action plan highlights that customer service and good quality accommodation are also key components sought by visitors to rural Wales (Welsh Government 2009). Woodward (2009) and The Organic Centre for Wales (2011) also highlighted the existence of a more 'green' and 'ethical group' of tourists that are seeking environmentally friendly accommodation and organic produce as features of their stay.

Rural populations in Wales are also changing. While some areas have experienced a population decline due to lack of economic opportunities others have experienced an influx of more affluent people moving in for lifestyle, retirement and employment purposes.

In summary tourists and leisure seekers have varied and evolving demands from their visit to the countryside which can provide opportunities for farmers looking to diversify their farms or further develop their farm tourism businesses. Farmers are well placed to cater for these opportunities due to the wide range of resources that they have available to them. However they need the skills to turn these resources into attractive tourism products.

\section{Farmers Resources and Capabilities}

Several authors have highlighted the resources and capabilities (Ploeg 2008, Scoones 1998 Grande 2011) required in order to diversify into new, non-farming activities. Grande's (2011) study highlights the 'critical resources and dynamic capabilities' required to create new ventures that perform well. In his study of new venture creation on small family farms in Norway he found that farms needed 'rare, valuable or unique resources' in order to achieve 'superior business performance.' He added that resources must possess some kind of value or enable the pursuit of certain business options. Key resources include physical, human, capital, technological and reputational ones. In the case of tourism, location is of importance too (Walford, 2001). With regards to tourism, whether a resource is desirable will depend on the experience that the tourist is seeking.

Grande (2011) also argues that these 'critical resources' are not enough on their own. In addition to these farmers also need what he calls 'dynamic capabilities' in order to identify new market opportunities and transform resources into new products. Several authors have examined the capabilities or entrepreneurial skills required to create new farm businesses that perform well (Morgan et al 2010, Phelan and Sharpley 2010). Grande (2011) highlights that dynamic capabilities enable farmers to explore and evaluate the resource base according to emerging needs and possibilities. He highlights that the presence of dynamic capabilities is usually determined by factors including: the farmer's education level and previous business experience. Grande's (2011) study found the key dynamic capabilities to be:

- The ability to sense market opportunities: This refers to the business operator's creativity and their continuous search for new ideas and ways to improve existing products. 
- The ability to integrate knowledge and physical resources to create new products: The resources available on the farm will have a certain importance to the new venture creation; however they need to be supplied with additional resources and knowledge to create prospering businesses.

- The ability to build networks: Networks can be formal or informal and can have various functions including: increasing access to customers, developing products and sharing knowledge.

- Market orientation: Promoting the new product and forming new relationships with the market

\section{Rationale and Methodology}

Farm diversification into tourism is an increasingly popular strategy in the UK and there are a growing number of studies that have examined the phenomena. Past studies in the UK have tended to take a quantitative approach and have examined factors that have influenced farmers to diversify and the type of diversification strategies that they have taken (McNally, 2001; Bowler et al 1996). However, many UK studies are now over a decade old and do not take into account changing agricultural policy or the development of the farm tourism sector over the past decade or so. In addition to this few studies have specifically examined the unique context of farm diversification into tourism in Wales. More recent studies on farm diversification in Northern Europe have taken a qualitative approach (Grande 2011, Brandth and Haugen 2011, Di Domenico and Miller 2010) in order to understand in more detail its complex processes.

This study has built on past research (the diversification strategies that farmers have taken) by examining in detail the resources and skills that farmers have drawn on in creating their farm tourism products. It draws on the concept of critical resources and dynamic capabilities put forward by Grande (2011) and applies it to the phenomena of farm tourism.

This study's aims were to:

- Identify the resources, specifically critical ones, that farm tourism operators have drawn on to create their farm tourism products

- Examine the dynamic capabilities that farmers have displayed and how these have contributed to the performance of their businesses

The study has specifically examined farm tourism businesses that were performing well, the definition of which, in this context, is that they are profitable and have a steady level of trade. The reason for this was to identify any factors or common themes that might have contributed towards the farm tourism business's performance.

A qualitative mini case - study approach was taken to enable the researcher to understand the unique context each farmer and the opportunities open to them in the development of their tourism enterprises. This approach also provided the researcher with an up to date account of farm tourism in Wales. This sample for this study consisted of six farmers with both old and new farm tourism businesses from across Wales that were performing well. The data was collected through semi-structured face to face interviews on the farm with questions focused around the research aims. Interviews were held with the person that was responsible for the decision making around the tourism business. The results were recorded in writing and organised beyond their raw state in tabular form under question and topic headings to enable analysis and the identifications of patterns and inconsistencies. The data was gathered in 2011 and 2012.

While the sample size was small, some general themes emerged throughout the findings and in some cases confirmed previous research. The findings identified the different strategies that farmers were following based on their specific situation. The findings are intended to be useful in providing guidance to other farmers looking to develop farm tourism businesses. Not all farmers will be able to explore their resources or possess the necessary dynamic capabilities to create attractive tourism products. 
The final aim of the study is to identify the extent to which agriculture (the working farm and farm produce) features as part of the farm tourism product and consider how it could feature more centrally.

\section{Findings: Farm and Farm Tourism Business Details}

Table 1 highlights key details of the farm tourism businesses featured in the study, along with the key features of their tourism products and markets that will be discussed in the findings. Although the de-activation of farm land is occurring in Wales, in the cases examined in the study none of the farms had marginalised their farming activities as a result of embarking on tourism. The study showed that in several cases the farm featured as a key part of the tourism product.

\begin{tabular}{|c|c|c|c|}
\hline Farm and Tourism Business Overview & $\begin{array}{l}\text { Rare, Valuable } \\
\text { and Unique } \\
\text { Resources }\end{array}$ & Customer Service & $\begin{array}{l}\text { Identifying Market } \\
\text { Opportunities }\end{array}$ \\
\hline $\begin{array}{l}\text { 1) James } \\
\text { Snowdonia National Park: } \\
\text { Farm: } 300 \text { acres, Conventional livestock } \\
\text { Tourism started 1950s } \\
\text { Campsite } \\
\text { Bed and Breakfast } \\
\text { Holiday Cottages } \\
\text { Family involvement: } 1 \text { part time }\end{array}$ & $\begin{array}{l}\text { Five-star holiday } \\
\text { cottages with } \\
\text { their own railway } \\
\text { halt on a popular } \\
\text { steam railway } \\
\text { line }\end{array}$ & $\begin{array}{l}\text { 'We enjoy meeting } \\
\text { people' } \\
\text { 'We like to tell } \\
\text { people about the } \\
\text { local area' }\end{array}$ & $\begin{array}{l}\text { 'Our main customers } \\
\text { are railway } \\
\text { enthusiasts, they } \\
\text { provide a year round } \\
\text { market for us' }\end{array}$ \\
\hline $\begin{array}{l}\text { 2) Brian } \\
\text { Brecon Beacons National Park: } \\
\text { Farm: } 200 \text { acres, Conventional livestock: } \\
\text { Pedigree Long Horn Cattle } \\
\text { Direct meat sales } \\
\text { Tourism started about } 30 \text { years ago } \\
\text { Castle access, Shop and Tearoom } \\
\text { Event catering venue } \\
\text { New seminar facility } \\
\text { Future plans: special event licence } \\
\text { Family involvement: } 2 \text { full time, } 1 \text { part } \\
\text { time }\end{array}$ & $\begin{array}{l}\text { A castle as a } \\
\text { tourist attraction } \\
\text { also provides an } \\
\text { atmospheric } \\
\text { backdrop for } \\
\text { events. } \\
\text { Home-made } \\
\text { local food ethos. }\end{array}$ & $\begin{array}{l}\text { 'We are good with } \\
\text { people' } \\
\text { 'We are reliable - if } \\
\text { we say we'll do } \\
\text { something then we } \\
\text { will' } \\
\text { 'First we will cater } \\
\text { for a wedding and } \\
\text { then a few years } \\
\text { later for a } \\
\text { christening' }\end{array}$ & $\begin{array}{l}\text { 'We identify new } \\
\text { market opportunities } \\
\text { and cater for them' } \\
\text { 'First it was selling } \\
\text { ice creams and now } \\
\text { it is catering for } \\
\text { weddings' } \\
\text { 'New opportunities? } \\
\text { 'Never say never!' }\end{array}$ \\
\hline $\begin{array}{l}\text { 3) Alfie } \\
\text { Snowdonia National Park: } \\
\text { Farm: } 1000 \text { acres over } 3 \text { farms } \\
\text { Conventional livestock } \\
\text { Property development } \\
\text { Tourism started in the } 1970 \text { s } \\
\text { Static caravan site, Campsite } \\
\text { Beauty shop } \\
\text { Family involvement:1 Full time } 2 \text { part } \\
\text { time }\end{array}$ & $\begin{array}{l}\text { Camping and } \\
\text { caravan site with } \\
\text { amazing } \\
\text { mountain views } \\
\text { Proximity to } \\
\text { walking and } \\
\text { cycling trails } \\
\text { based in a } \\
\text { national park }\end{array}$ & $\begin{array}{l}\text { 'I like to thank } \\
\text { people personally' } \\
\text { 'I listen to } \\
\text { customer feedback } \\
\text { and do something } \\
\text { about it' }\end{array}$ & $\begin{array}{l}\text { 'When I saw the } \\
\text { view I thought I can } \\
\text { sell this!' }\end{array}$ \\
\hline $\begin{array}{l}\text { 4) Dave } \\
\text { Ceredigion in Mid Wales: } \\
\text { Farm: } 450 \text { acres, Organic livestock } \\
\text { Residential letting } \\
\text { Tourism started in } 2009 \\
\text { Event catering venue } \\
\text { Future plans: Accommodation for event } \\
\text { guests } \\
\text { Family involvement: } 4 \text { part time }\end{array}$ & $\begin{array}{l}\text { Family- run event } \\
\text { catering business } \\
\text { and restaurant } \\
\text { serving good- } \\
\text { quality, simple } \\
\text { local food that } \\
\text { appeals to a wide } \\
\text { audience }\end{array}$ & $\begin{array}{l}\text { 'We are a family } \\
\text { business and like } \\
\text { to provide a } \\
\text { personal touch for } \\
\text { our customers' } \\
\text { 'It's hard to find } \\
\text { staff with the same } \\
\text { attitude and } \\
\text { enthusiasm' }\end{array}$ & $\begin{array}{l}\text { 'We saw a gap in the } \\
\text { local market' }\end{array}$ \\
\hline
\end{tabular}




\begin{tabular}{|c|c|c|c|}
\hline $\begin{array}{l}\text { 5) Tom and Liz } \\
\text { Ceredigion in Mid Wales: } \\
\text { Farm: } 150 \text { acres, Organic livestock and } \\
\text { horticulture } \\
\text { Tourism started in } 2009 \\
\text { Glamping' (luxury / glamorous camping) } \\
\text { in yurts } \\
\text { Farm shop } \\
\text { Future plans: additional accommodation } \\
\text { units } \\
\text { Family involvement: } 1 \text { Full time } 2 \text { part } \\
\text { time }\end{array}$ & $\begin{array}{l}\text { Eco-friendly } \\
\text { glamping in yurts } \\
\text { on an organic } \\
\text { farm in lush, } \\
\text { green } \\
\text { countryside. } \\
\text { The main } \\
\text { attraction is } \\
\text { being in on the } \\
\text { farm and meeting } \\
\text { the animals }\end{array}$ & $\begin{array}{l}\text { 'Personal service } \\
\text { and attention to } \\
\text { detail are } \\
\text { important' }\end{array}$ & $\begin{array}{l}\text { 'We feel that we got } \\
\text { into the (glamping) } \\
\text { market at the right } \\
\text { time' } \\
\text { 'Holidays on organic } \\
\text { working farms are } \\
\text { also growing in } \\
\text { popularity' }\end{array}$ \\
\hline $\begin{array}{l}\text { 6) Samantha } \\
\text { Snowdonia National Park: } \\
\text { Farm: } 100 \text { acres: Conventional Sheep } \\
\text { Tourism started in } 2004 \\
\text { Bed and Breakfast, Bunkhouse \& } \\
\text { Campsite } \\
\text { Future plans: Camping pods (huts) } \\
\text { Family involvement: } 1 \text { Full time } 1 \text { part } \\
\text { time }\end{array}$ & $\begin{array}{l}\text { Proximity to a } \\
\text { key mountain } \\
\text { biking centre }\end{array}$ & $\begin{array}{l}\text { 'We could talk to } \\
\text { people all day. We } \\
\text { tell them all about } \\
\text { the farm' } \\
\text { 'Some regular } \\
\text { customers are } \\
\text { becoming more } \\
\text { like friends' }\end{array}$ & $\begin{array}{l}\text { 'The bank were } \\
\text { happy to lend us the } \\
\text { money, even going } \\
\text { into recession, } \\
\text { because of the } \\
\text { popularity of the } \\
\text { mountain biking } \\
\text { centre' }\end{array}$ \\
\hline
\end{tabular}

Tab 1. Farm Tourism Business: Key Features (adapted from Talbot 2012) (Farmers names have been changed to protect their identity).

The first three farm tourism businesses are well established starting over 30 years ago while farms four and five started since 2008. Farm six was taken over by the current owners in 2009 but the tourism business had been in operation since 2004. On all of the farms family members play a key role in running the tourism business and in five of the farms more than one generation is involved in either farming or tourism. In most cases the wife played a key role in the tourism business.

\section{Farm resources and tourism products}

In the interviews farmers identified the resources that they had drawn on in creating their tourism products and the aspects of their farm tourism product that they felt had contributed towards the performance of their tourism business. These are highlighted in Table 1 under: Rare, valuable and unique resources. These can be categorised as the location, the surrounding natural and cultural heritage; as well as the commercial goods, which include the use of the farm as part of the tourist experience, the farm land and buildings, farm produce, customer service and business ethos.

\section{Location}

The market advantage that farmers felt they had in terms of their location included:

Proximity to heritage attractions: James' farm is situated on a popular steam railway line, a relic from the area's mining history, which is a key tourist attraction in the area. There is also railway halt on the farm to collect the guests staying there who are mostly railway enthusiasts.

Proximity to outdoor activities: With the growing popularity of outdoor activities farms located in areas for walking, cycling and other activities have a market advantage. Samantha's farm is the closest to a major purpose built mountain biking centre and mountain bikers provide $90 \%$ of their trade.

Heritage sites on the land: Some farms can benefit from special sites on their land. Brian's farm has a castle which attracts sightseeing tourists to the farm. The castle also acts as an atmospheric backdrop for his event business.

Views: Views are a resource that many tourism operators capitalise on that may be difficult to market if it were not for tourism. Mountain views were the catalyst in the development of Alfie's camping and caravan site. He stated: 'When I saw the view I thought I can sell this! 
National Park locations: Popular areas within national parks are often an immediate draw with tourists due to the opportunities they provide to experience a high quality environment and aspects of local culture. Also there is generally good road access to the national parks in the North and South of Wales from England compared to Mid Wales. While this may provide market advantages for farm tourism businesses located there, there is a lot of accommodation on the market so farmers will still need to differentiate their products and provide an attractive product in order for their businesses to perform well.

Previous research (Walford 2001) has highlighted that tourism works best in areas with an attractive natural environment and good road access. This study has highlighted what some of the specific locational benefits at farm level were found to be.

\section{Commercial goods}

In terms of commercial goods, the resources drawn on in creating the farm tourism product include:

The farm itself: Farming and tourism can be symbiotic as the farm experience can form part of the tourism product (Busby and Rendle 2000). The farm environment can be used as an attractive backdrop to a farm holiday or the farm itself can be used as the context for the visit providing visitors with the opportunity to learn about farming, interact with farm animals and consume local produce (Philips et al 2010). The later provides a more authentic experience, the kind that tourists are increasingly expecting. Farms in Wales are well-suited for farm tourism as they are livestock farms and Busby and Rendle (2000) note that farms with animals have a greater visual appeal for visitors. Farmers in the study have relied to varying degrees on the appeal and authenticity of the farm setting in creating their tourism products. The study has identified three main approaches to incorporating the farm.

Tom and Liz developed a glamping (glamorous or luxury camping) campsite on Tom's parents' organic mixed farm (livestock and horticulture). They use the farm as a key component of their product by running farm tours for their overnight guests and providing them with the experience of looking after and feeding the animals (cows, pigs, sheep and chickens). To better facilitate this activity they had selected gentle breeds that provided a better animal and human interaction: 'Herefords (cattle) are gentle with tourists'. They stated that on the farm tours they aimed to provide tourists with a better understanding of food production and country life. Some farms may be better suited to providing farm based experiences than others. Due to the mix of activities on their farm and the availability of family members to conduct the farm tours it lends itself well to such an approach.

Brian has taken the approach of adapting his farming activities to make the farm more attractive to tourists. Urry (1990) noted that the act of viewing the countryside is not a neutral activity and found that tourists often transform the rural place gazed upon in their minds to meet their own preconceptions of a 'rural idyll.' In making his farm more attractive for tourists Brian has stated that he had selected an old native breed of cattle (Long horns) for their aesthetic qualities adding that: 'they bring the place to life.' He also added that: 'I don't engage in smelly activities such as silage making' and 'There are ducks and chickens on the yard, that's not normal on a farm these days.' Many farm tourism entrepreneurs have responded to the expectations of nostalgic tourists, by gentrifying their farms, removing activities that might spoil the tourist experience of the countryside, and adding elements that might enhance it, as in Brian's example. And they have a motive to. Brian added 'what we do is for the tourists as they provide us with a key part of our income.'

Both Tom and Liz and Brian have changed their agricultural activities and routines to cater for tourists. They feel that their approach has added to the appeal of their product. Tom and Liz felt based on their experience that 'Holidays on organic working farms are also growing in popularity'

Other farms (James' and Alfie's) have not attempted to feature the working farm as part of the tourist experience and they keep tourism and agriculture separate. However as the farms are livestock based the farm setting is likely to feature to a certain degree. Clark (1996) 
described farm tourism as that in which the consumer is aware of the farming environment as a minimum.

Farm land and buildings: Farmers are often well placed to develop accommodation and tourist facilities due to the land and building resources they have available. All of the farmers have had access to redundant or underutilised resources, particularly buildings, rooms and land and have brought them into use by using them to create their farm tourism businesses. The farm tourism business creation has been influenced by both the resources available on the farm and market opportunities identified by the farmer. For example Tom and Liz took over the least productive but most scenic field on the farm to develop their glamping business. James had attractive traditional style farm buildings next to the railway line which were no longer fit for the purpose of housing livestock and developed these into holiday cottages named after the steam engines that travel on the line past his farm. The use of traditional buildings and the incorporation of a railway theme to the accommodation have helped to create a 'sense of place' on the farm. In developing their tourism businesses three of the farm tourism operators interviewed stated that they had benefitted from Rural Development Programme grants and advice, highlighting its importance. Other sources of funding that farmers stated they had drawn on included savings, bank and family loans and the SFP. The farmers with the two new businesses indicated that they had relied significantly on family labour and technical skills as well as farm machinery to create their facilities which reduced start-up costs considerably.

Farm produce: More and more tourists are seeking the gastro-idyll, organic produce and locally produced food. Some farms are well placed to provide home grown food for their guests and research by the Welsh Government's Food Tourism Action Plan 2009 shows that it adds appeal to the tourism product of both the hosting venue and in terms of overall distinctiveness for the region. This study provides several examples of farmers catering for this demand. The provision of food has also provided these farmers with additional income sources.

Tom and Liz provide organic food hampers sourced from their parent's farm for guests staying in their yurts. They also have a farm shop where guests can buy further supplies. They are well placed to do this due to the range of agriculture on their farm: horticulture, eggs and meat production.

Brian provides catering in his tea shop and for his event guests. He draws on the farm produced, locally sourced, home-made and traditional elements of his food products in appealing to guests. He provides farm produced beef, and homemade food including cakes, ice-cream and traditional Welsh dishes such as 'Cawl' a vegetable and meat stew. Dave's restaurant also focuses on sourcing quality local produce. They do not offer their home farmed meat specifically due to fluctuating customer demand and the demand for popular meat cuts only. He buys his meat from the local butcher as needed and stated that he may well be buying his own meat back (as many farmers' produce ends up in supermarkets across the UK it would be difficult for them to follow this approach). Brian is able to provide his own beef to his guests as he follows the strategy of providing 'meat boxes' directly to his customers. The boxes contain a variety of meat cuts. To make these he kills several animals a year and this approach provides him with a supply of meat for his catering business too. Providing farm produce to customers is not always a straight forwards strategy particularly in the case of beef and sheep farming and extra investment of time and resources is required by farmers following this route.

Being able to offer locally sourced food depends on there being adequate and reliable supplies. The bed and breakfast operators in the study indicated that locally sourced ingredients were not always easy to find.

The farm family and their service: One of the key features that tourists expect from a rural holiday is good customer service (Welsh Government 2009). Interpersonal skills are of key importance for the hospitality sector and Busby and Rendell (2000) noted the increasing professionalism of the farm tourism sector as businesses grew and a greater part of the income was derived from tourism.

In listing the factors that had contributed towards the performance of their farm tourism business a recurrent theme was their focus on personal contact and looking after their guests well. Most 
of the farmers stated that they liked to 'greet their guests on arrival' and 'thank them personally for their visit.' Farmers taking overnight guests added that they 'enjoyed meeting new people' or 'we are good with people' and stated that they were available to 'tell people about the farm' and 'what to do in the local area.' An important aspect here is the farm family's farming experience and embeddedness in their local community. Five of the farmers have been farming in their community for many years. As such they are well placed to provide descriptions of agriculture and rural life. Another farmer added that some of their guests had become more like friends and that they invited them in for drinks. This was also beneficial for the farm family too as it provided them with some social contact, a benefit that has been cited in past studies of farm tourism in sparsely populated areas (Ollenburg and Buckley 2007).

Farmers also highlighted how they catered for guests' needs. For example Dave explained how they aimed to provide a personal touch for different customers visiting their restaurant and how at an $80^{\text {th }}$ birthday party they had created a special atmosphere by bringing the family around the piano to sing songs. He felt that they are able to achieve this as they are committed family members working together in their own business. He stated that it was hard to find staff with the same attitude and enthusiasm.

Customer service is a new role for farmers and catering for guests can be a change to farming routines. In many cases setting up farm tourism brings family members, particularly female ones, back to the farm for self-employment purposes. The examples in this study show that there is family involvement in every business and in five out of six cases two generations are involved in farming and/or tourism activities and in five cases the wife played a key role. The availability and involvement of family labour means that they are more likely to have the capacity to provide a high level of customer service. The customer service that farming families offer will vary from farm to farm depending on what farm tourism hosts perceive to be important and the activities that farmers offer.

Contact with the farm family is an important element of the stay. Busby and Rendell (2000) note that staying on a farm and enjoying family style hospitality is a post-industrial tourist experience as it provides a personal approach that is often lost in purpose built modern resorts and city hotels.

Business ethos: A business ethos is the principles and ethics by which a business conducts its activities. The need for businesses to act responsibly towards wider society and the natural environment in which they operate is well documented and businesses that adhere to such principles can have market appeal (Goodwin and Francis 2003). The business ethos can be related to the farm or the farm tourism business. Tom and Liz's tourism business has an organic and eco-friendly business ethos, which is based on their own and their family's values. They found that the fact that they were a long-established organic farm had great appeal to many of their guests. Tom and Liz also produce their own renewable energy to power the campsite. They use solar panels to generate electricity for the showers and cooking area and have installed a wind turbine to draw water from underground. They also sourced their yurts from local, sustainably produced materials where available. However they found that the eco-friendly aspect of their product was less appealing to their customers, which they felt was due to overuse of the term by less scrupulous businesses.

These examples show how farmers have adapted elements of their farm and farming routine in order to create synergies with the farm tourism product. Some farm tourism operators have multiple strategies that complement each other. Some farm and family contexts may lend themselves better to certain tourist activities than others. The examples highlight the main resources that farmers have drawn on in creating attractive tourism products and aspects of these that have contributed towards their business's performance. While some farmers have clear locational advantages, they have all have relied on their commercial creation, a tourism product that has market appeal. 


\section{Dynamic Capabilities}

Resources cannot explore themselves. Farmers need what Grande (2011) refers to as dynamic capabilities to enable them to respond to evolving market opportunities and transform their resources into attractive tourism products. The key dynamic capabilities that Grande identified include:

- The ability to sense market opportunities

- The ability to integrate knowledge and physical resources to develop tourism products

- The ability to build networks

- Market orientation

This section examines the presence and application of these dynamic capabilities in the development and promotion of the farm tourism businesses in this study.

\section{Sensing market opportunities and developing products}

All of the farmers in the study have identified and realised market opportunities by transforming their resources into products that meet market needs (see Table 1). The examples in this study include:

Niches: Examples of niche markets catered for in this study include railway enthusiasts and mountain bikers. The majority of James' visitors are railway enthusiasts due to the farm's location on the railway line. They are, on average, older tourists, seeking more comfortable accommodation which he provides with his five star holiday cottages. Many of them are repeat visitors and they provide a year round market in a largely seasonal area. However he recognises that as this market gets older he may have to seek new groups. Another example is Samantha's farm which is located close to a key purpose built mountain biking centre. Here the guests, often groups of men, come for mountain biking breaks nearly all year round. The mix of accommodation (bed and breakfast, camping and bunkhouse) and on Samantha's farm works well and the bunkhouse, the most recent development, is particularly popular for accommodating groups. However, as it is a relatively small bunkhouse they can't always accommodate larger groups. This sometimes loses them trade. In both of these examples the farm tourism operators are in the fortunate position of being in locations that provide them with a clear market advantage. However, they have still provided products that are attractive to the market that they are catering for. It is not always possible to rely on location alone to achieve a high level of trade in today's competitive market and the commercial offering is also of importance as if customers' needs are not met they may go elsewhere. These two examples of niche markets draw on the core offering of the area and provide trade that is mostly year round and more weather resistant. As such they make an important contribution to the Welsh Tourism Product.

Gaps: More affluent people are moving to parts of rural Wales for retirement, lifestyle and employment purposes. Ceredigion in Wales is a county that has seen one of the largest growth rates in population in recent years. That is a growth of $26 \%$ since 1980 . The past few decades have seen a growing and well-paid, public-sector work force in some rural areas of Wales (Milboune 2011). This more affluent population means that they are more likely to have more disposable income for a variety of leisure purposes, one of which is eating out. Dave identified a lack of quality catering facilities in his area of rural Wales away from the main tourist destinations and felt there was a gap in the market in terms of providing good-quality, locally produced food for the local population. Based on exploring this idea further through market research Dave and his family opened their catering business in 2009. They cater for Sunday lunches, events (including weddings) and social gatherings, particularly for the local community. As Dave's family did not have any catering experience they bought in external support to set up their kitchen and develop their menu as well as a wedding planner to show them how to cater for weddings. Dave's business provides an example of how integrating new knowledge with existing resources can create an attractive tourism product. 
Trends: In recent years glamping in yurts has become popular in the UK due to our inclement weather. According to Knight's (2010) Cool Camping Guide 'Yurts, which were quite a rare sighting just a few years, are now everywhere!' Tom and Liz felt that one of the main reasons for their business's high level of occupancy was that they had got into the glamping market at the right time, just as it was starting to grow. In addition to this they feel that they had established themselves by 'doing it well' and had built a good reputation.

Continuous business development: Brian is continuously searching for new business ideas. He has adopted the approach of growing his farm tourism business by identifying new opportunities as they emerge and catering for them. He started off catering for tourists 30 years ago by selling ice-creams and cakes to people visiting the castle and gradually added new income streams as the opportunity arose. These include developing: a shop and tearoom an event catering venue, direct meat supplies, the creation of a new seminar centre and obtaining a licence to hold wedding ceremonies on his land. In terms of the future business activities he says: 'never say never!' if he sees a suitable opportunity he will cater for it. This phased approach to growth, an approach that most farmers in the study seem to be following, is less risky as it enables farmers to try new ideas out and make financial investments in stages.

Maintaining product quality and upgrading facilities: Farmers are continuing to maintain the quality of and upgrade their tourism products in order to meet market needs. They are doing this, both in response to customer feedback and by pre-empting customer needs. For example Alfie stated that he 'always listens to customer feedback' and did something about any complaints or suggestions. As a result of feedback he has recently upgraded the shower block and levelled out more pitches for camping. Samantha is exploring the idea of installing camping pods (small wooden huts) on their farm which provide a convenient alternative to camping particularly when the weather is bad.

Business reputation: All of the tourism businesses are maintaining or increasing levels of patronage as they have developed a positive business reputation. Several farmers stated that many of their bookings were either from repeat business or from customer recommendations. Brian stated 'first we will cater for their wedding and then a few years later for the christening'. He added that they get repeat trade and recommendations as 'we are reliable, if we say we will do something then we will.' A good reputation is a valuable resource and repeat business and customer recommendations made up a large proportion of customers for the group of farmers interviewed.

\section{Market orientation and networks}

As a result of developing farm tourism businesses, farmers need to form market relationships with a new set of customers (Ploeg and Roep 2003). This can be a challenge. Today many farm tourism businesses have an internet presence and this is true of this group. They either have their own websites, or are part of a themed website: e.g. UK Camping or an area marketing group e.g. Visit Mid Wales and this has helped them connect with a wider audience. The findings here show the additional ways that members of this group of farmers have developed market relationships. These include positive publicity, networks and the use of social media.

All three new businesses reported having exceeded expected patronage levels for their early years of trading which the operators feel is as a result of positive reports on their businesses. For example: Tom and Liz's glamping business received publicity in a Sunday national newspaper travel section after a journalist had stayed on their farm. They felt that their increased trade had been as a result of this. They were also included in Knight's (2010) 'Cool Camping' guide book which claims to find 'extra special places to camp' in which they also received positive reviews: The guide highlighted that 'they know what they are doing and they do it very well!' Dave's business received positive coverage on the Welsh language TV channel as well as in rural life consumer magazines, which he thought helped to increase trade. Online forums are another method of recommending businesses and Samantha stated that her business gets a lot of positive publicity on mountain biking forums which has resulted in further bookings. 
Farmers working in cooperation with others as part of an online marketing group promoting their region rather than their individual farm unit found it an effective strategy. For example one group of farm tourism operators found that proximity to natural heritage provided them with a market advantage. 'Croeso Cader Idris' or 'Welcome to Cader Idris Mountain' is the name of the marketing group and the website that is used to promote holidays on Welsh family farms around the well-known mountain area. The name Cader Idris was used rather than that of individual farms as it is more common for people to search the destination area that they wished to travel to.

Those using social media are able to have a more intimate relationship with past and potential guests. Recent posts on Tom and Liz's Facebook site have included video footage of their new accommodation unit as well as announcements and photos on the arrival of spring: of swallows arriving and calves frolicking in the meadows. While they are updating (potential) customers on life in the countryside, they are also creating a rural idyll in their customers' minds. Most of the posts on Dave's Facebook site are in the Welsh language, highlighting that his business is very much embedded in the local community. His family cater for many local community events including farming unions and local women's groups. His family have both social and professional connections with these groups, and this has resulted in bookings.

The farmers in this study have demonstrated that they possess the necessary dynamic capabilities to explore their resource base and develop and maintain well performing businesses. The examples show that farmers have developed tourism businesses that cater for a wide range of evolving markets. They have identified niches gaps and trends to cater for and developed tourism products that have appeal to their markets, in these cases: railway enthusiasts, mountain bikers, families, day trippers, the local market and those seeking local food or catering for an event. They have also focussed on maintaining the quality of their product and updating it so that their product continues to have market appeal. In developing and maintaining their products farm tourism operators have sought new knowledge by: conducting market research, getting input from catering industry professionals and obtaining feedback from customers. They have forged relationships with the market beyond the standard internet advertisement (their webpage or presence on a group site) including the use of the media, networks and social media as well as building up their business reputation. These factors are all likely to have contributed towards their business performance.

\section{Discussion and conclusions}

\section{Key research findings}

This study has examined the experience of six farm tourism businesses in Wales. This study's aims were to:

- Identify the resources, specifically critical ones, that farm tourism operators have drawn on to create their farm tourism products

- Examine the dynamic capabilities that farmers have displayed and how these have contributed to the performance of their businesses

The study has examined the experience of farm tourism operators whose businesses were performing well with the aim of identifying any factors or common themes that might have contributed towards this. As this is a small sample it is not possible to generalise the findings. What the results do show is the variety of tourism products that farmers have developed based on their own unique contexts: their resource base, the markets opportunities posed in their location and their dynamic capabilities. The findings from this study can provide ideas for farmers wishing to develop their farm tourism businesses as it provides examples on how they might draw on their resource base as well as providing examples of the dynamic capabilities that farmers have drawn on to create appealing tourism products. Farmers elsewhere may be able to apply some of these ideas to their own contexts.

The study has shown that tourists and leisure seekers have a variety of evolving demands from the countryside and the research shows that farm tourism operators are catering for these by 
offering a wide range of products. Their products also cover a wide range of budgets so farm tourism businesses may be impacted differently during the current economic downturn. The study has shown that farmers are well placed to cater for tourists visiting the countryside due to the wide range of resources that they have to draw on in creating their tourism products and the synergies that they are able to create between farming and tourism which can add to the appeal of the tourism product. The study has highlighted that farms in Wales generally lend themselves well to farm tourism as they are small, in scenic areas, are live-stock based, often feature traditional style buildings and draw on the hospitality of the farm family.

This study has identified the key resources that farmers have drawn on in creating their farm tourism products, particularly the ones that have market appeal and have provided them with superior business performance. The main resources that farmers have drawn on in creating their tourism products are summarised in table two below. The resources include: the location, the working farm, farm land and buildings, farm produce, the farm family, the business ethos and business reputation. The different farm contexts including: market opportunities available in the area, the type of agriculture followed, the availability of family labour, the resources on the farm and the dynamic capabilities of farm family members will have all influenced the farm tourism strategy selected.

The research has shown that the farm tourism operators in the study possess the necessary dynamic capabilities to develop and maintain farm tourism businesses that are able to perform well. Resources cannot explore themselves and farmers have shown that they have the ability to explore their resource base and recognise its value. They have demonstrated the ability to combine and draw on their resources as well as integrate new resources and knowledge in order to transform the resources into attractive farm tourism products that cater for evolving tourism markets needs. Farm tourism operators in the study have demonstrated both their ability to sense market opportunities by identifying market gaps, niches and trends to cater for as well as the ability to maintain the quality and utility of their product so that it continues to have market appeal. They have not relied on attributes such as locational benefit alone but they have created products that have met the needs of the market that they are catering for which is necessary in increasingly competitive markets. They have also demonstrated their ability to develop their market relationships beyond their internet advertisement (their webpage or presence on a group site) through repeat bookings and customer recommendations, positive publicity, the use of formal and informal networks and social media. All of these factors are likely to have contributed to a steady or growing level of patronage for the farm tourism businesses in the study. While farm tourism in Wales is a growing sector (Nilsson 2002), the findings suggest that there are still market opportunities for farm tourism products that are market led which can be seen from the new businesses that were established during the recession.

\begin{tabular}{|c|c|c|}
\hline Resource & Features & Notes \\
\hline 1. Location & $\begin{array}{l}\text { Location advantages can include: } \\
\text { - } \quad \text { proximity to key attractions and activities } \\
\text { - } \quad \text { special features on the land (for example } \\
\text { - } \quad \text { archaeological sites) } \\
\text { - } \quad \text { national park location }\end{array}$ & $\begin{array}{l}\text { A high quality environment and } \\
\text { good access can provide } \\
\text { location advantages. However, } \\
\text { location may not be enough on } \\
\text { its own. Farmers still need to } \\
\text { create products that meet the } \\
\text { requirements of their main } \\
\text { markets in order to perform well. }\end{array}$ \\
\hline $\begin{array}{ll}2 . & \text { The } \\
\text { working } \\
\text { farm }\end{array}$ & $\begin{array}{l}\text { Farmers have taken three main approaches to } \\
\text { incorporating the farm into their tourism product: } \\
\text { using the farm as the key focus of the tourist } \\
\text { experience (for example: providing farm tours } \\
\text { and opportunities to interact with the animals) } \\
\text { adapting farming activities to make the farm } \\
\text { more attractive to tourists (for example the } \\
\text { addition of attractive breeds and removal of } \\
\text { uncongenial activities) } \\
\text { keeping both farming and tourism separate, } \\
\text { so that the farm is only the backdrop }\end{array}$ & $\begin{array}{l}\text { The approach taken will depend } \\
\text { on the farm context. However, } \\
\text { even where farming is kept } \\
\text { separate to tourism, tourists are } \\
\text { still likely to be aware of the } \\
\text { farm environment to some } \\
\text { degree }\end{array}$ \\
\hline
\end{tabular}




\begin{tabular}{|c|c|c|c|}
\hline & $\begin{array}{l}\text { The farm } \\
\text { land and } \\
\text { buildings }\end{array}$ & $\begin{array}{l}\text { Farmers have brought old, redundant and } \\
\text { underutilised resources back into us to create their } \\
\text { tourism products. Such resources include: } \\
\text { - rooms } \\
\text { - buildings } \\
\text { - } \quad \text { fields } \\
\text { attractive countryside settings }\end{array}$ & $\begin{array}{l}\text { Farmers have used these } \\
\text { resources to create products } \\
\text { with an authentic appeal. } \\
\text { Access to finance is necessary } \\
\text { to transform these resources } \\
\text { and Rural Development } \\
\text { Programmes have provided } \\
\text { grants and advice to support } \\
\text { this process. }\end{array}$ \\
\hline 4. & $\begin{array}{l}\text { Farm } \\
\text { produce }\end{array}$ & $\begin{array}{l}\text { Farmers have drawn on the following as part of their } \\
\text { tourism product: } \\
\text { - farm produced goods } \\
\text { - locally produced goods } \\
\text { - } \quad \text { home-maditional recipes } \\
\text { hood }\end{array}$ & $\begin{array}{l}\text { The type of agriculture followed, } \\
\text { the availability of locally } \\
\text { produced goods and the type of } \\
\text { farm tourism product offered will } \\
\text { impact upon a farmer's ability to } \\
\text { draw on this as a resource }\end{array}$ \\
\hline & $\begin{array}{l}\text { The farm } \\
\text { family }\end{array}$ & $\begin{array}{l}\text { Aspects of farm family engagement in the farm } \\
\text { tourism business include: } \\
\text { - } \text { meeting and serving guests } \\
\text { - } \text { giving guided tours of the farm } \\
\text { - } \text { providing a personalised service } \\
\text { - the formation of friendships with guests } \\
\text { the physical construction of the business }\end{array}$ & $\begin{array}{l}\text { Farm family engagement in the } \\
\text { farm tourism business will } \\
\text { depend on the availability and } \\
\text { capabilities of family members }\end{array}$ \\
\hline & $\begin{array}{l}\text { Business } \\
\text { ethos }\end{array}$ & $\begin{array}{l}\text { In order to appeal to customers farmers have drawn } \\
\text { on their business principles and ethics. They have } \\
\text { drawn on both: } \\
\text { aspects of their farming business (for } \\
\text { example: organic farming) } \\
\text { aspects of their tourism businesses (for } \\
\text { example: environmental policy and customer } \\
\text { service) }\end{array}$ & $\begin{array}{l}\text { This study provides examples of } \\
\text { how farmers have incorporated } \\
\text { their own values into the tourism } \\
\text { product. However in other } \\
\text { cases, the promotion of such } \\
\text { product aspects can also be } \\
\text { used as a marketing ploy. }\end{array}$ \\
\hline & $\begin{array}{l}\text { Business } \\
\text { reputation }\end{array}$ & $\begin{array}{l}\text { Farmers have built their reputations up over time } \\
\text { based on the quality and utility of their tourism } \\
\text { products. The business's reputation can result in } \\
\text { repeat bookings and recommendations, which can } \\
\text { contribute towards the level of trade. }\end{array}$ & $\begin{array}{l}\text { A business's reputation is both } \\
\text { a resource that farmers have } \\
\text { created and one on which they } \\
\text { can draw to attract customers in } \\
\text { the future. }\end{array}$ \\
\hline
\end{tabular}

Tab 2. Resources that farmers in Wales have drawn on in creating their farm tourism products.

\section{Farm tourism and agriculture}

The findings highlight that farm tourism products do vary in the extent to which they feature agriculture: the working farm and farm produce as part of the farm tourism product. Results show that there seem to be two main approaches that farm tourism operators are following:

- Farm based tourism: where agriculture is central to the farm tourism product and the working farm and / or its produce is the main part of the appeal.

- Tourism that takes place on farms: where agriculture is peripheral to the farm tourism product and the working farm is a backdrop to the visit. Access to the rural environment, attractions and activities are the key part of the appeal

The approach taken is not necessarily an either or, but present more a continuum on the extent to which the agricultural context is integrated into the tourism product. Different types of farms and farm contexts may lend themselves better to different approaches to farm tourism. These different approaches to farm tourism development in the developed world have been noted by Busby and Rendle (2000) and Garrod (2011).

Given the variety of tourist markets being catered for and the different contexts that farmers find themselves in it is important to note that these have both been important approaches in terms of supporting agriculture and developing a distinctive tourism product for Wales. Farm tourism has 
been proven to generate additional incomes to support farm households and enable the continuation of farming (Busby and Rendell, 2000; Ploeg, 2008). Farm tourism can therefore protect the very resource on which it depends as it's the landscape that the farmers create and manage which provides a key part of the product appeal. In addition to supporting agriculture farm tourism can address rural decline by providing another industry in rural areas. In recognition of these benefits past Rural Development Plan initiatives have supported the development of farm tourism through the provision of advice and grants to develop tourist accommodation and amenities.

However, the study concludes that there is scope for a greater focus on agriculture in the farm tourism sector in Wales and that this could lead to a more distinctive farm tourism product. As already noted recent research suggests that tourists are increasingly expecting the working farm context as part of their stay and the opportunity to consume high quality locally produced food. As a result, there are likely to be more opportunities for developing tourism products based around agriculture. This research has shown that this can be a beneficial strategy for farmers to follow both in terms of attracting visitors and in generating extra revenues from the sale of farm produce and home-made food. A stronger focus on agriculture can also provide the opportunity for urban people that are detached from countryside to learn about food production and rural life. The working farms and farm produce of the Welsh hills and Valleys are expressions of local culture and a greater focus on agriculture can add to a stronger farm tourism product, a stronger sense of place and stronger tourism product in general for Wales.

While some farmers in the study are following the approach of integrating the working farm and its produce into their tourism product it is very much based on their own initiative and resources (time and labour) rather than it being a cohesive approach guided by government policy. While policy acknowledges that there are more opportunities for synergy between agriculture and tourism, this research has also shown that there are challenges to putting agriculture more centrally in the tourism product. One of the key challenges identified both in this study and in The Welsh Government's Farming Food and The Countryside Strategy (FFCS) (2009) is that of supplying farm and local produce to tourism businesses. The strategy highlights the need for a more integrated approach here and this has been detailed in the subsequent Food Tourism Action Plan (2009). A key focus of the action plan is to improve the supply chain between producers and the tourism industry in order to increase the availability of local produce. Research findings from this study indicate that there is scope for further progress here.

The FFCS strategy also highlights that there are opportunities for farmers to develop tourism products that draw more on agriculture and the farming landscape which can add value to the farm tourism sector; however it does not contain the detail for action at a farm level. Further value can be added to the farm tourism sector by focussing on the development of the farm tourism activities, beyond accommodation, that incorporate agriculture or by better integrating aspects of the farm into the farm tourism accommodation offering in order to promote a stronger sense of place through the farm. The different types of farm tourism activities noted by Clarke (1996) were listed earlier in this study and these provide ideas for how agriculture might be better integrated into the farm tourism product. They include: The development of tourist amenities on farms that draw on agricultural produce including retail and catering; the development of farm based attractions and activities that can provide visitors with a greater understanding of farming and the countryside; improving access to the countryside through leisure activities and farm trails; and hosting events such as farm open days and demonstrations. These examples all draw more on agriculture and could complement the existing farm tourism products. This research shows that some farmers are already following some of these strategies.

\section{Recommendations}

Going into the future, while there may be new opportunities in farm tourism not all farmers will be equipped to take advantage of these. The first recommendation is that farmers be made aware of the policy direction of farm tourism in Wales and be provided with the necessary support in developing tourism products that meet this. Such support should include strengthening the dynamic capabilities of farmers and providing them with information on 
relevant market trends. This way they will be able to more effectively explore their resource base and develop tourism products that meet market needs.

The second recommendation is the development of a farm tourism strategy that brings together the elements that contribute to the farm tourism sector as a whole: the working farm, farm produce, landscape and nature, leisure, accommodation, attractions and amenities. Such a strategy could provide cohesive guidance for the future development of the sector and highlight the important role farm tourism can play in contributing towards a strong Welsh tourism product.

\section{References}

[1] Bateman, D. \& Ray, C. (1994). Farm Pluri-activity and Rural Policy: Evidence from Wales, Journal of Rural Studies 10(1), 1-13. Doi: 10.1016/0743-0167(94)90002-7.

[2] Bowler, I., Clark, G., Crocket, A., Ilbery, B. \& Shaw, A. (1996). The Development of Alternative Farm Enterprises: A Study of Family Labour Farms in the North Pennines of England, Journal of Rural Studies, 12(3), 285-295. Doi: 10.1016/0743-0167(96)00015-0.

[3] Brandth, B. \& Haugen, M. (2011). Farm diversification into tourism - Implications for social identity? Journal of Rural Studies, 27(1), 35-44. Doi: 10.1016/j.jrurstud.2010.09.002.

[4] Busby, G. and Rendle, S. (2000). The Transition from Tourism on Farms to Farm Tourism, Tourism Management, 21(6), 635-642. Doi: 10.1016/S0261-5177(00)00011-X.

[5] Clarke, J. (1996). Farm tourism, Insights, January 19-24.

[6] Clarke, J. (1999). Marketing structures for farm tourism: beyond the individual provider of rural tourism. Journal of Sustainable Tourism, 7(1), 26-47. Doi: $10.1080 / 09669589908667325$.

[7] Cloke, P. \& Perkins, H. C. (2002). Commodification and Adventure in New Zealand Tourism, Current Issues in Tourism, 5(6), 521-49. Doi: 10.1080/13683500208667939.

[8] Dartington Amenity Research Trust (1974). Farm recreation and tourism in England and Wales. Countryside Commission Publications 83, London: Countryside Commission.

[9] Defra (2007) Rural Development Plan for England. London: Department for Environment, Food and Rural Affairs.

[10] Di Domenico M. \& Miller G. (2012). 'Farming and tourism enterprise: Experiential authenticity in the diversification of independent small-scale family farming'. Tourism Management 33(2), 285-294. Doi: 10.1016/j.tourman.2011.03.007.

[11] Garrod, B. (2011). Diversification into Farm Tourism: Case studies from Wales. Oxford: Goodfellow.

[12] Grande, J. (2011). New venture creation in the farm sector: Critical resources and capabilities, Journal of Rural Studies 27(2), 220-233. Doi: 10.1016/j.jrurstud.2011.02.003.

[13] Great Britain Tourism Survey Volume and Value 2012.

[14] Goodwin, H., \& Francis, J. (2003). Ethical and responsible tourism: consumer trends in the UK. Journal of Vacation Marketing, 9(3), 271-284. Doi: 10.1177/135676670300900306.

[15] Ilbery, B. W. (1991). Farm diversification as an adjustment strategy on the urban fringe of the West Midlands, Journal of Rural Studies 7(3), 207-218. Doi: 10.1016/07430167(91)90085-7.

[16] Knight, J. (2010). Cool Camping Wales, London: Punk Publishing.

[17] Lopez-i-Gelats, F., Milán, M. J. \& Bartolomé, J. (2011) Is farming enough in mountain areas? Farm diversification in the Pyrenees, Land Use Policy, 28(4), 783-791. Doi: 10.1016/j.landusepol.2011.01.005. 
[18] McNally, S. (2001). Farm Diversification in England and Wales: What can we learn from the farm business survey? Journal of Rural Studies, 17(2), 247-257. Doi: 10.1016/S07430167(00)00050-4.

[19] Meert, H., Van Huylenbroeack, G., Bourgeois, M. \& VanHecke, E. (2005). Farm Household Survival Strategies and Diversification on Marginal Farms. Journal of Rural Studies 21(1), 81-97. Doi: 10.1016/j.jrurstud.2004.08.007.

[20] Milbourne, P. (2011). Rural Wales in the Twenty First Century. Cardiff: University of Wales Press.

[21] Morgan, S. L., Marsden, T., Miele, M., Morley, A., (2010). Agricultural multifunctionality and farmers' entrepreneurial skills: A study of Tuscan and Welsh farmers, Journal of Rural Studies 26(2), 116-129. Doi: 10.1016/j.jrurstud.2009.09.002.

[22] Nilsson, P. A. (2002). Staying on farms: An ideological background. Annals of Tourism Research 29(1), 7-24. Doi: 10.1016/S0160-7383(00)00081-5.

[23] Ollenburg, C. \& Buckley, R. (2007). Stated Economic and Social Motivations of Farm Tourism Operators. Journal of Travel Research 45(4), 444-452. Doi: $10.1177 / 0047287507299574$.

[24] Office for National Statistics (2012). Rural and urban areas: comparing lives using rural/urban classifications, Regional Trends 43, 2010/2011.

[25] Philips, S., Hunter, C. \& Blackstock, K. (2010). A typology for Defining Agri-tourism, Tourism Management 31(6), 754-758. Doi: 10.1016/j.tourman.2009.08.001.

[26] Phelan, C. \& Sharpley, R. (2012). Exploring entrepreneurial skills and competencies in farm tourism, Local Economy 27(2), 103-118. Doi: 10.1177/0269094211429654.

[27] Ploeg, J. D. \& Roep, D. (2003). Chapter 3, Multifunctionality and rural development: the actual situation in Europe (pp. 37-53). In Hylenbroeck, G. \& Durand. G., eds., Multifunctional agriculture a new paradigm, Aldershot: Ashgate.

[28] Ploeg, J. D. (2008). The New Peasantries: Struggles for Autonomy and Sustainability in an era of Empire and Globalisation, London: Earthscan.

[29] Scoones, I. (1998). Sustainable Rural Livelihoods: A Framework for Analysis. Working Paper 72. Brighton: Institute for Development Studies.

[30] Smith, S. (1994). The Tourism product. Annals of Tourism Research, 21(3), 582-595. Doi: 10.1016/0160-7383(94)90121-X.

[31] Talbot, M. (2012). Farm Diversification and Farm Tourism in Wales: The experience of $\begin{array}{llll}\text { entrepreneurial farmers. Regions } & \text { 22-25. }\end{array}$ Doi: 10.1080/13673882.2012.10515101.

[32] The Organic Centre for Wales (2011). Why sustainable agri-tourism is a market opportunity for the organic sector. Aberystwyth: Organic Centre for Wales.

[33] Urry, J. (1990). The Tourist Gaze. London: Sage.

[34] Wales Tourist Board (2005). Sense of Place Toolkit, Cardiff: WTB.

[35] Walford, N. (2001). Patterns of Development in Tourist Accommodation Enterprises on Farms in England and Wales. Applied Geography 21(4), 331-345. Doi: 10.1016/S01436228(01)00010-8.

[36] Walmsley, J. \& Jenkins, J. (2003). Leisure. In J. Jenkins \& J. Pigram, eds., Encyclopaedia of Leisure and Outdoor Recreation. London: Routledge.

[37] Welsh Economic Research Unit (2010). Tourism Satellite Account for Wales 2007. Cardiff University.

[38] Welsh Government Statistical Bulletin, (2008). Farm Diversification in Wales 2007. 
[39] Welsh Government, Results from the Farm Business Survey (2007). Available at: www.wales.gov.uk/statistics (retrieved 01.11.10).

[40] Welsh Government (2009). Food Tourism Action Plan.

[41] Welsh Government (2009). Farming Food and the Countryside Strategy.

[42] Welsh Government Statistical Bulletin (2008): Farm Diversification in Wales 2007.

[43] Welsh Government (2006). Tourism Strategy for Wales: Achieving Our Potential.

[44] Welsh Rural Observatory (2010). Survey of farming households in Wales. Cardiff \& Aberystwyth Universities.

[45] Woods, M. (2011). Rural, London: Routledge.

[46] Woodward, A. (2009). Today's Opportunities in Farm Tourism, Tourism Insights. 